\title{
Comparison of hypertension control
} in patients with diabetes and hypertension and patients with hypertension without diabetes depending on the stage of chronic kidney disease

\section{ABSTRACT}

Diabetes and hypertension are plagues of the beginning of the 21 st century. Both of these conditions lead to significant deterioration in quality of life and reduction of patient's life expectancy. The aim of the work was to answer the questions: what is the all day, daily and night systolic and diastolic blood pressure in patients with hypertension and in patients with diabetes and hypertension, depending on the stage of chronic kidney disease, and whether there are significant differences in the control of day and night systolic and diastolic blood pressure between the patients with diabetes mellitus and hypertension. 300 patients have been admitted to the Department of Internal Diseases, Diabetology and Nephrology due to hypertension decompensation. In the first place all subjects were divided into two groups: the ones with diabetes and hypertension and patients with hypertension but without diabetes. Afterwards the patients were divided in 5 subgroups depending on the stage of chronic kidney disease. It was shown that patients with diabetes and hypertension are significantly less likely to have their

Address for correspondence:

prof. dr hab. n. med. Władysław Grzeszczak

Katedra i Klinika Chorób Wewnętrznych, Diabetologii i Nefrologii

Śląskiego Uniwersytetu Medycznego

ul. 3 Maja 13/15, 41-800 Zabrze

e-mail:wgrzeszczak@sum.edu.pl

Translation: GROY Translations

Clinical Diabetology 2017, 6, 3, 81-89

DOI: $10.5603 /$ DK.2017.0014

Received: 15.05.2017

Accepted: 09.08.2017 blood pressure controlled properly ( 24 hours a day, during the day and at night) in relation to patients with hypertension without diabetes and that, with increased renal failure, diabetes and hypertension and hypertensive patients without diabetes do not have good blood pressure control, especially for diabetics and hypertension. (Clin Diabetol 2017; 6, 3: 81-89)

Key words: diabetes, hypertension, kidney failure, control

\section{Introduction}

In Poland, about 3.1 million people are patients suffering from diabetes and over 10 million patients suffering from hypertension [1]. Many patients suffering from diabetes are also diagnosed with hypertension. Both diabetes and hypertension cause a significant deterioration in the quality of life as well as the reduction of a patient's life expectancy [2,3]. It is only the good control of diabetes and hypertension that may prevent or postpone the period of occurrence of complication development in these patients [4-7]. In patients with diabetes and without it, together with the progressive development of the disease there is deterioration in the hypertension control [8]. Treatment of these patients should be more aggressive, namely it should require the application of several drugs of various mechanisms of action $[9,10]$.

With regard to the above, it was decided to find the answer to the following questions: 
1. What is the state of systolic and diastolic blood pressure, over the period of 24 hours, during the day and at night in patients with hypertension and in patients with diabetes and hypertension?

2. What is the state of systolic and diastolic blood pressure over the period of 24 hours, during the day and at night in patients with hypertension and in patients with diabetes and hypertension depending on the stage of chronic kidney disease?

3. If there are any significant differences in control of the systolic and diastolic blood pressure during the day and at night between the patients with hypertension and patients with diabetes and hypertension?

\section{Material and methods}

In order to obtain an answers to the questions raised, further 300 patients were admitted to the Department of Internal Diseases, Diabetology and Nephrology in Zabrze, Medical University of Silesia in Katowice. The reason for the admission was either the uncontrolled hypertension and diabetes or uncontrolled hypertension without diabetes, within the period of 1.01.2013-31.12.2013. Basic tests and the assessment of the daily blood pressure profile were performed among the admitted patients. The average age of the study subjects was $61 \pm 15$ years, average height 1.66 \pm 0.09 metres, average body weight $84.20 \pm 18 \mathrm{~kg}$ and the average BMI $31.19 \pm 8.23 \mathrm{~kg} / \mathrm{m}^{2}$. The average duration of hypertension was $14.06 \pm 8.74$ years. On admission, the average systolic blood pressure was 150 $\pm 9 \mathrm{~mm} \mathrm{Hg}$ and the average diastolic blood pressure was $88 \pm 18 \mathrm{~mm} \mathrm{Hg}$.

In the first place all subjects were divided into two groups of patients : with diabetes and hypertension and patients with hypertension but without diabetes.

188 patients were assigned to the group of patients with diabetes and hypertension. The average age of the study subjects was $64.16 \pm 12$ years, average height $1.64 \pm 0.09$ metres, average body weight $86.54 \pm 19.49 \mathrm{~kg}, \mathrm{BMI} 32.18 \pm 9.15 \mathrm{~kg} / \mathrm{m}^{2}$. The average duration of diabetes was $11.41 \pm 8.69$ years, and of hypertension was $13.01 \pm 8.2$. On admission the average systolic blood pressure was $52 \pm 26 \mathrm{~mm} \mathrm{Hg}$, and the average diastolic blood pressure was $86 \pm$ $15 \mathrm{~mm} \mathrm{Hg} .112$ patients were assigned to the group with hypertension without diabetes. The average age of the study subjects was $57.41 \pm 17.08$ years, average height $1.64 \pm 0.09$ metres, average body weight $78.40 \pm 14.78 \mathrm{~kg}, \mathrm{BMI} 29.03 \pm 5.22 \mathrm{~kg} / \mathrm{m}^{2}$. The average duration of hypertension was $12.47 \pm 8.29$ years. On admission, the average systolic blood pressure was 149 $\pm 25 \mathrm{~mm} \mathrm{Hg}$, and the average diastolic blood pressure was $90 \pm 24 \mathrm{~mm} \mathrm{Hg}$.

Patients with diabetes and hypertension in relation to patients with diabetes without hypertension were: 1. significantly older, 2 . had considerably greater body weight and 3. had substantially higher BMI. There were no differentiations in the average duration time of hypertension and systolic and diastolic blood pressure between the patients with diabetes and hypertension and patients with hypertension and without diabetes.

Subsequently the whole group was divided into 5 subgroups depending on the stage of chronic kidney disease (CKD), which included respective study subjects.

58 patients were assigned to stage I of CKD group with eGFR $>90 \mathrm{~mL} / \mathrm{min} / 1.73 \mathrm{~m}^{2} .68$ patients were assigned to stage II of CKD group with eGFR $60-90 \mathrm{~mL} / \mathrm{min} / 1.73 \mathrm{~m}^{2}$. 108 patients were assigned to stage III of CKD group with eGFR $30-59 \mathrm{~mL} / \mathrm{min} / 1.73 \mathrm{~m}^{2} .52$ patients were assigned to stage IV of CKD group with eGFR 15-29 mL $/ \mathrm{min} / 1.73 \mathrm{~m}^{2} .14$ patients were assigned to stage $V$ of CKD group with eGFR $<15 \mathrm{~mL} / \mathrm{min} / 1.73 \mathrm{~m}^{2}$ (Tab. 1).

The data presented in table I showed that the subgroups under study displayed statistically significant differences in all essential considered parameters except the diastolic blood pressure.

Each of the study groups I-V (depending on the stage of chronic kidney disease) were divided into two subgroups: the study subjects with diabetes and hypertension (subgroup a) and the study subjects with hypertension without diabetes (subgroup b). Table 2 presents anthropometric parameters and blood pressure values regarding the entire group of patients divided into subgroups according to the stage of chronic kidney disease.

The subgroups under study did not significantly differ statistically among one another, except for the group IIla and group Ib, which differed significantly in such parameters as age, body weight and BMI. The above-studied subgroups did not differ statistically in terms of blood pressure measured on admission.

Measurement of the body weight and height was performed using a mechanical physician scale with height rod of AED company. 24-hour automatic blood pressure measurement was performed with a registrar - Oscar 2 of Oxford company, model Oscar 2, number 97-0012-00. Blood pressure was measured every 20 minutes during the day (6.00-22.00) and every 30 minutes at night. The limit of normal for average blood pressure when awake was set at the value of $135 / 85 \mathrm{~mm} \mathrm{Hg}$ and for average blood pressure when asleep was 120/80 mm Hg [11]. The concentration of creatinine in the blood was examined in all the studied subjects and it was performed with Jaffe kinetic 
Table 1. Anthropometric parameters and readings of blood pressure on admission to hospital in respective subgroups of patients divided according to the stages of chronic kidney disease

\begin{tabular}{|c|c|c|c|c|c|c|c|}
\hline $\begin{array}{l}\text { Groups of the } \\
\text { study subjects } \\
\text { depending on } \\
\text { the stage of } \\
\text { chronic kidney } \\
\text { disease }\end{array}$ & $\begin{array}{c}\text { Age } \\
\text { [years] }\end{array}$ & $\begin{array}{c}\text { Height } \\
{[\mathrm{m}]}\end{array}$ & $\begin{array}{c}\text { Weight } \\
{[\mathrm{kg}]}\end{array}$ & $\begin{array}{c}\text { BMI } \\
{\left[\mathrm{kg} / \mathrm{m}^{2}\right]}\end{array}$ & $\begin{array}{c}\text { Average } \\
\text { duration of } \\
\text { hypertension } \\
\text { [years] }\end{array}$ & $\begin{array}{c}\text { Average } \\
\text { duration } \\
\text { of systolic } \\
\text { blood } \\
\text { pressure } \\
\text { [mm Hg] }\end{array}$ & $\begin{array}{c}\text { Average } \\
\text { duration } \\
\text { of diastolic } \\
\text { blood } \\
\text { pressure } \\
\text { [mm Hg] }\end{array}$ \\
\hline I & $52.6 \pm 13.73$ & $1.66 \pm 0.09$ & $85.43 \pm 22.09$ & $32.36 \pm 12.81$ & $10.78 \pm 8.86$ & $150 \pm 25$ & $87 \pm 14$ \\
\hline II & $61.69 \pm 14.83$ & $1.63 \pm 0.09$ & $84.58 \pm 19.68$ & $31.10 \pm 7.54$ & $13.98 \pm 8.89$ & $158 \pm 31$ & $91 \pm 23$ \\
\hline III & $64.82 \pm 14.23$ & $1.64 \pm 0.09$ & $83.74 \pm 16.4$ & $31.04 \pm 5.70$ & $13.89 \pm 7.83$ & $150 \pm 25$ & $89 \pm 20$ \\
\hline IV & $65.96 \pm 14.7$ & $1.64 \pm 0.07$ & $82.57 \pm 16.41$ & $30.67 \pm 5.81$ & $16.80 \pm 8.71$ & $142 \pm 28$ & $82 \pm 15$ \\
\hline V & $58.28 \pm 12.14$ & $1.68 \pm 0.04$ & $75.6 \pm 10.99$ & $26.61 \pm 4.36$ & $18.14 \pm 11.07$ & $153 \pm 29$ & $84 \pm 12$ \\
\hline $\begin{array}{l}\text { Statistical } \\
\text { significance } \\
\text { of differences } \\
\text { (ANOVA test) }\end{array}$ & 0.0001 & 0.0001 & 0.0001 & 0.0001 & 0.0001 & 0.0281 & NS \\
\hline
\end{tabular}

Table 2. Anthropometric parameters and readings of blood pressure of the study subjects in the previously named subgroups

\begin{tabular}{|c|c|c|c|c|c|c|c|}
\hline $\begin{array}{l}\text { Stage of chronic } \\
\text { kidney disease } \\
\text { (CKD) of the } \\
a \text { and b } \\
\text { subgroup }\end{array}$ & $\begin{array}{c}\text { Age } \\
\text { [years] }\end{array}$ & $\begin{array}{c}\text { Height } \\
{[\mathrm{m}]}\end{array}$ & $\begin{array}{l}\text { Weight } \\
{[\mathrm{kg}]}\end{array}$ & $\begin{array}{c}\text { BMI } \\
{\left[\mathrm{kg} / \mathrm{m}^{2}\right]}\end{array}$ & $\begin{array}{c}\text { Average } \\
\text { duration of } \\
\text { hypertension } \\
\text { [years] }\end{array}$ & $\begin{array}{c}\text { Average } \\
\text { duration of } \\
\text { systolic blood } \\
\text { pressure } \\
\text { [mm Hg] }\end{array}$ & $\begin{array}{c}\text { Average } \\
\text { diastolic } \\
\text { blood } \\
\text { pressure } \\
\text { [mm Hg] }\end{array}$ \\
\hline la, $n=45$ & $55.80 \pm 11.34$ & $1.65 \pm 0.09$ & $87.23 \pm 22.8$ & $33.31 \pm 13.24$ & $11.82 \pm 8.39$ & $151 \pm 23$ & $86 \pm 10$ \\
\hline $\mathrm{lb}, \mathrm{n}=11$ & $39.54 \pm 15.57$ & $1.69 \pm 0.08$ & $71.4 \pm 14.5$ & $39.54 \pm 15.57$ & $6.45 \pm 8.92$ & $147 \pm 33$ & $90 \pm 22$ \\
\hline Ila, $n=43$ & $63.44 \pm 13.12$ & $1.63 \pm 0.09$ & $88.05 \pm 20.53$ & $31.78 \pm 8.12$ & $16.27 \pm 9.65$ & $159 \pm 28$ & $88 \pm 11$ \\
\hline Ilb, $n=26$ & $58.8 \pm 17.26$ & $1.61 \pm 0.10$ & $76.14 \pm 14.9$ & $58.8 \pm 17.26$ & $10.04 \pm 5.67$ & $154 \pm 35$ & $98 \pm 35$ \\
\hline IIIa, $n=63$ & $68.80 \pm 11.02$ & $1.60 \pm 0.09$ & $88.18 \pm 17.19$ & $32.68 \pm 5.8$ & $14.76 \pm 8.19$ & $151 \pm 24$ & $88 \pm 19$ \\
\hline IIIb, $n=46$ & $59.24 \pm 16.35$ & $1.64 \pm 0.1$ & $78.26 \pm 13.76$ & $59.24 \pm 16.35$ & $12.6 \pm 7.20$ & $147 \pm 27$ & $90 \pm 21$ \\
\hline Iva, $n=34$ & $68.32 \pm 13.24$ & $1.63 \pm 0.07$ & $79.9 \pm 15.66$ & $30.00 \pm 6.21$ & $18.11 \pm 8.63$ & $144 \pm 30$ & $82 \pm 15$ \\
\hline $\mathrm{IVb}, \mathrm{n}=18$ & $61.6 \pm 16.60$ & $1.67 \pm 0.07$ & $89.25 \pm 17.36$ & $61.5 \pm 16.60$ & $14.17 \pm 7.20$ & $139 \pm 22$ & $82 \pm 15$ \\
\hline Va, $n=3$ & $58.33 \pm 8.02$ & $1.7 \pm 0.04$ & $80 \pm 13$ & $27.68 \pm 4.36$ & $9 \pm 8.9$ & $150 \pm 28$ & $82 \pm 13$ \\
\hline $\mathrm{Vb}, \mathrm{n}=11$ & $58.27 \pm 13.3$ & $1.68 \pm 0.04$ & $74.5 \pm 12.36$ & $58.27 \pm 13.3$ & $20.63 \pm 8.5$ & $154 \pm 27$ & $85 \pm 13$ \\
\hline
\end{tabular}

method. Subsequently, the creatinine clearance was defined, using the Cockroft-Gault equation [12].

\section{Statistical analysis}

Normally distributed data were presented as mean \pm standard deviation. Data deviating from a normal distribution and ordinal data were given as median and upper and lower quantiles. The quality data were displayed in the form of percentage; the assessment of the distribution normality of the obtained results was performed against the Shapiro-Wilk test. The variables, which were considered to be statistically significant parameters, displayed the significance level $p$, which was less than 0.05 . The calculations were performed using the Statistica 8.0 version PL and Excel Microsoft Office Package programs.

\section{Permission to conduct research}

In the light of the Law of 5 December 1996 on the professions of physicians and dentists (i.e. Journal of Laws of 2011 No. 277, item 1634 as amended) the aforementioned study is not a medical experiment and does not require the assessment of the Bioethics Committee of SMU in Katowice (03.05.2014). 
Table 3. Daily values of systolic and diastolic blood pressure and pulse pressure in the entire group of the study subjects and in patients with and without diabetes

\begin{tabular}{lcccc}
\hline Parameter & $\begin{array}{c}\text { The studied group } \\
\mathbf{n}=\mathbf{3 0 0}\end{array}$ & $\begin{array}{c}\text { Patients with } \\
\text { diabetes } \mathbf{n}=\mathbf{1 8 8}\end{array}$ & $\begin{array}{c}\text { Patients without } \\
\text { diabetes } \mathbf{n}=\mathbf{1 1 2}\end{array}$ & $\begin{array}{c}\text { Statistical significance of differences } \\
\text { between patients with and without diabetes }\end{array}$ \\
\hline $\mathrm{SBP}_{\text {average }}$ & $139 \pm 21$ & $140 \pm 20$ & $138 \pm 21$ & $\mathrm{NS}$ \\
$\mathrm{SBP}_{\text {max }}$ & $197 \pm 20$ & $177 \pm 22$ & $210 \pm 23$ & 0.014 \\
$\mathrm{SBP}_{\text {min }}$ & $108 \pm 18$ & $108 \pm 17$ & $109 \pm 21$ & $\mathrm{NS}$ \\
$\mathrm{DBP}_{\text {average }}$ & $77 \pm 12$ & $76 \pm 11$ & $79 \pm 14$ & 0.026 \\
$\mathrm{DBP}_{\text {max }}$ & $105 \pm 21$ & $106 \pm 22$ & $103 \pm 20$ & $\mathrm{NS}$ \\
$\mathrm{DBP}_{\text {min }}$ & $55 \pm 11$ & $54 \pm 10$ & $57 \pm 13$ & 0.003 \\
\hline
\end{tabular}

Table 4. Daily values of systolic and diastolic blood pressure in the entire group of the study subjects divided according to the stages of chronic kidney disease

\begin{tabular}{lcccccc}
\hline Parameter & $\begin{array}{c}\text { Stage 1 CKD } \\
\mathbf{n}=\mathbf{5 8}\end{array}$ & $\begin{array}{c}\text { Stage 2 CKD } \\
\mathbf{n}=\mathbf{6 8}\end{array}$ & $\begin{array}{c}\text { Stage 3 CKD } \\
\mathbf{n}=\mathbf{1 0 8}\end{array}$ & $\begin{array}{c}\text { Stage 4 CKD } \\
\mathbf{n}=\mathbf{5 2}\end{array}$ & $\begin{array}{c}\text { Stage 5 CKD } \\
\mathbf{n}=14\end{array}$ & $\begin{array}{c}\text { Statistical significance } \\
\text { of differences between } \\
\text { the subgroups under study }\end{array}$ \\
\hline $\mathrm{SBP}_{\text {average }}$ & $139 \pm 20$ & $138 \pm 25$ & $138 \pm 18$ & $140 \pm 20$ & $143 \pm 19$ & $\mathrm{NS}$ \\
$\mathrm{SBP}_{\max }$ & $175 \pm 23$ & $169 \pm 15$ & $172 \pm 23$ & $175 \pm 24$ & $166 \pm 20$ & $\mathrm{NS}$ \\
$\mathrm{SBP}_{\min }$ & $107 \pm 17$ & $108 \pm 19$ & $107 \pm 18$ & $107 \pm 20$ & $121 \pm 20$ & $\mathrm{NS}$ \\
$\mathrm{DBP}_{\text {average }}$ & $78 \pm 12$ & $77 \pm 13$ & $76 \pm 11$ & $76 \pm 13$ & $78 \pm 12$ & $\mathrm{NS}$ \\
$\mathrm{DBP}_{\max }$ & $109 \pm 26$ & $105 \pm 23$ & $104 \pm 18$ & $101 \pm 21$ & $100 \pm 17$ & $\mathrm{NS}$ \\
$\mathrm{DBP}_{\min }$ & $55 \pm 10$ & $54 \pm 11$ & $54 \pm 10$ & $56 \pm 12$ & $61 \pm 13$ & $\mathrm{NS}$
\end{tabular}

\section{Results}

Daily (average, maximum, minimum) values of systolic and diastolic blood pressure in the entire group of the study subjects, including the patients with diabetes and hypertension and patients with hypertension without diabetes (Tab. 3).

The conducted research showed no differences between the daily systolic blood pressure in patients with diabetes and hypertension and patients with hypertension without diabetes. Daily diastolic blood pressure was significantly higher in patients with hypertension without diabetes. No differences were demonstrated both in systolic and diastolic blood pressure when measured during the day. At night the systolic blood pressure was higher in patients with diabetes than without diabetes.

The provided criteria recommendations for the daily blood pressure control were not met by $33.33 \%$ patients in the entire group, $36.88 \%$ in the group of patients with diabetes and hypertension and $31.81 \%$ in the group of patients with hypertension without diabetes. Substantially statistically significant difference between the patients with hypertension with diabetes and without diabetes was shown $(p<0.001)$.
Daily (average, maximum, minimum) values of systolic and diastolic blood pressure in the group of the study subjects divided according to the stages of chronic kidney disease (Tab. 4).

No significant differences were demonstrated in the values of systolic and diastolic blood pressure when measured over the period of 24 hours and during the day between the patients with hypertension without diabetes at different stages of CKD.

Daily (average, maximum, minimum) values of systolic and diastolic blood pressure in the entire group of patients with diabetes depending on the development of chronic kidney disease stage in them (Tab. 5).

No significant differences were demonstrated in the values of systolic blood pressure over the period of 24 hours, during the day and at night in the studied groups of patients with diabetes and hypertension depending on the stage of chronic kidney disease.

Daily (average, maximum, minimum) values of systolic and diastolic blood pressure in the entire group of patients with hypertension without diabetes depending on the stage of chronic kidney disease (Tab. 6).

No significant differences were demonstrated in the values of systolic blood pressure over the period 
Table 5. Daily values of systolic and diastolic blood pressure in the group of patients with diabetes and hypertension depending on the stage chronic kidney disease

\begin{tabular}{lcccccc}
\hline Parameter & Stage 1 & Stage 2 & Stage 3 & Stage 4 & Stage 5 & $\begin{array}{c}\text { Statistical significance } \\
\text { of differences between } \\
\text { the subgroups under study }\end{array}$ \\
\hline $\mathrm{SBP}_{\text {average }}$ & $140 \pm 20$ & $139 \pm 27$ & $140 \pm 20$ & $140 \pm 15$ & $140 \pm 23$ & $\mathrm{NS}$ \\
$\mathrm{SBP}_{\text {max }}$ & $176 \pm 24$ & $181 \pm 22$ & $177 \pm 23$ & $178 \pm 21$ & $166 \pm 28$ & $\mathrm{NS}$ \\
$\mathrm{SBP}_{\text {min }}$ & $108 \pm 18$ & $109 \pm 18$ & $109 \pm 18$ & $106 \pm 16$ & $121 \pm 7$ & $\mathrm{NS}$ \\
$\mathrm{DBP}_{\text {average }}$ & $80 \pm 11$ & $76 \pm 12$ & $75 \pm 11$ & $74 \pm 11$ & $78 \pm 13$ & $\mathrm{NS}$ \\
$\mathrm{DBP}_{\text {max }}$ & $113 \pm 28$ & $106 \pm 20$ & $105 \pm 22$ & $100 \pm 21$ & $99 \pm 12$ & $\mathrm{NS}$ \\
$\mathrm{DBP}_{\min }$ & $56 \pm 10$ & $53 \pm 11$ & $53 \pm 9$ & $55 \pm 11$ & $56 \pm 8$ & $\mathrm{NS}$ \\
\hline
\end{tabular}

Table 6. Daily values of systolic and diastolic blood pressure in patients with hypertension without diabetes depending on the stage of chronic kidney disease

\begin{tabular}{lcccccc}
\hline Parameter & Stage $\mathbf{1}$ & Stage $\mathbf{2}$ & Stage 3 & Stage 4 & Stage $\mathbf{5}$ & $\begin{array}{c}\text { Statistical significance } \\
\text { of differences between } \\
\text { the subgroups under study }\end{array}$ \\
\hline $\mathrm{SBP}_{\text {average }}$ & $136 \pm 24$ & $138 \pm 24$ & $136 \pm 18$ & $141 \pm 29$ & $147 \pm 19$ & $\mathrm{NS}$ \\
$\mathrm{SBP}_{\text {max }}$ & $173 \pm 24$ & $173 \pm 24$ & $168 \pm 24$ & $171 \pm 31$ & $167 \pm 21$ & $\mathrm{NS}$ \\
$\mathrm{SBP}_{\text {min }}$ & $105 \pm 16$ & $109 \pm 23$ & $105 \pm 18$ & $111 \pm 26$ & $125 \pm 20$ & $\mathrm{NS}$ \\
$\mathrm{DBP}_{\text {average }}$ & $76 \pm 17$ & $80 \pm 15$ & $79 \pm 13$ & $81 \pm 15$ & $80 \pm 12$ & $\mathrm{NS}$ \\
$\mathrm{DBP}_{\text {max }}$ & $98 \pm 20$ & $104 \pm 28$ & $105 \pm 14$ & $106 \pm 23$ & $102 \pm 20$ & $\mathrm{NS}$ \\
$\mathrm{DBP}_{\text {min }}$ & $55 \pm 13$ & $58 \pm 13$ & $55 \pm 13$ & $60 \pm 14$ & $64 \pm 14$ & $\mathrm{NS}$ \\
\hline
\end{tabular}

Table 7. The percentage of patients not obtaining proper blood pressure control in both the entire study group and individual subgroups, over the period of 24 hours as well as during the day and at night

\begin{tabular}{lccccccc}
\hline Parameter & $\begin{array}{c}\text { Patients with } \\
\text { diabetes }\end{array}$ & $\begin{array}{c}\text { Patients } \\
\text { without } \\
\text { diabetes }\end{array}$ & $\begin{array}{c}\text { Patients with } \\
\text { stage 1 CKD }\end{array}$ & $\begin{array}{c}\text { Patients with } \\
\text { stage 2 CKD }\end{array}$ & $\begin{array}{c}\text { Patients with } \\
\text { stage 3 CKD }\end{array}$ & $\begin{array}{c}\text { Patients with } \\
\text { stage 4 CKD }\end{array}$ & $\begin{array}{c}\text { Patients with } \\
\text { stage 5 CKD }\end{array}$ \\
\hline $\begin{array}{l}\text { Over the period } \\
\text { of 24 hours }\end{array}$ & 36.88 & 31.81 & 22.75 & 33.82 & 42.22 & 43.07 & 50.00 \\
$\begin{array}{l}\text { During the day } \\
\text { At night }\end{array}$ & 42.29 & 40.90 & 29.65 & 35.29 & 42.40 & 42.69 & 50.00 \\
\hline
\end{tabular}

of 24 hours, during the day and at night in the studied groups of patients with hypertension depending on the stage of chronic kidney disease.

Differences between the data presented in Table 5 and Table 6 are non-statistically significant.

The percentage of patients whose blood pressure was not controlled properly in both the entire study group and individual subgroups, over the period of 24 hours as well as during the day and at night is presented in Table 7.

The percentage of patients not obtaining proper blood pressure control over the period of 24 hours as well as during the day and at night was significantly higher in patients without diabetes (Tab. 8).

The number of patients whose daily blood pressure does not equalize over the period of 24 hours, during day and at night increases together with the stage of CKD.

The percentage of patients not obtaining proper blood pressure control in individual subgroups, both over the period of 24 hours as well as during the day and at night and the statistical significance of differences between the subgroups of patients with diabetes and hypertension and patients with hypertension 
Table 8. Statistical significance of differences between the group of patients with hypertension and diabetes and without diabetes who do not obtain proper blood pressure control

\begin{tabular}{lc}
\hline Parameter & $\begin{array}{c}\text { Statistical significance of differences } \\
\text { between the group of patients } \\
\text { with hypertension and diabetes } \\
\text { and without diabetes }\end{array}$ \\
\hline $\begin{array}{l}\text { Over the period } \\
\text { of } 24 \text { hours }\end{array}$ & $p<0.05$ \\
$\begin{array}{l}\text { During the day } \\
\text { At night }\end{array}$ & $p<0.05$ \\
\end{tabular}

without diabetes, depending on the stage of chronic kidney disease (Tab. 9).

Diabetics with 1, 2 or 4 stage of chronic kidney disease obtained worse control of blood pressure than patients without diabetes.

\section{Discussion}

The conducted research showed that the values of blood pressure in patients with diabetes and without diabetes were significantly higher than the values considered to be normal, despite the applied treatment. This suggests that the anti-hypertensive treatment that was carried out in the study participants was not conducted aggressively enough. Both in patients with diabetes and in patients without diabetes hypertension requires appropriate treatment. This is associated with the behavioral treatement (diet and physical effort) and pharmacological one. Behavioral treatment is difficult as, according to dietary guidelines, all patients with hypertension should cut down on salt intake. There are many products with high salt content on the market and it is very difficult to eliminate them. Moreover, in patients with hypertension it is usually required to use several anti-hypertensive agents, the selection of which is also not simple.

Unfortunately, the lack of blood pressure control increases the risk of complications (especially cardiovascular diseases) [13].

Significantly more patients with diabetes and hypertension, in comparison to the number of patients with hypertension and without diabetes did not obtain correct blood pressure values. Patients with diabetes are exposed to very high risk of complications, particularly cardiovascular complications, in comparison to patients without diabetes. Polish Scientific Associations (PTNT) [14], and European Scientific Associations (ESH) [15] publish guidelines considering the proper treatment in order to control the patients' blood pressure. As it turns out, the studies that we conducted show that it is often impossible to control the blood pressure to a satisfactory degree. It applies, to a much greater extent, to patients with diabetes and hypertension. How then can this fact be explained? It seems very likely that in patients with diabetes the progression of

Table 9. The percentage of patients not obtaining proper blood pressure control in individual subgroups, both over the period of 24 hours as well as during the day and at night

\begin{tabular}{|c|c|c|c|c|c|}
\hline Parameter & $\begin{array}{l}\text { Patients with } \\
\text { stage } 1 \text { CKD }\end{array}$ & $\begin{array}{l}\text { Patients with } \\
\text { stage } 2 \text { CKD }\end{array}$ & $\begin{array}{l}\text { Patients with } \\
\text { stage } 3 \text { CKD }\end{array}$ & $\begin{array}{l}\text { Patients with } \\
\text { stage } 4 \text { CKD }\end{array}$ & $\begin{array}{l}\text { Patients with } \\
\text { stage } 5 \text { CKD }\end{array}$ \\
\hline \multicolumn{6}{|l|}{ Over the period of 24 hours } \\
\hline Patients with diabetes & 33.33 & 32.55 & 22.22 & 37.64 & 53.33 \\
\hline Patients without diabetes & 36.36 & 34.61 & 21.73 & 33.33 & 54.54 \\
\hline \multicolumn{6}{|l|}{ During the day } \\
\hline Patients with diabetes & 42.22 & 34.88 & 25.39 & 29.41 & 53.33 \\
\hline Patients without diabetes & 36.36 & 34.61 & 31.30 & 38.88 & 54.54 \\
\hline \multicolumn{6}{|l|}{ At night } \\
\hline Patients with diabetes & 48.88 & 53.48 & 41.26 & 51.17 & 53.33 \\
\hline Patients without diabetes & 36.36 & 38.46 & 36.95 & 40.00 & 45.45 \\
\hline \multirow[t]{3}{*}{ Parameter } & \multicolumn{5}{|c|}{ Statistical significance of differences in subgroups of patients } \\
\hline & \multicolumn{5}{|c|}{ with and without diabetes depending on the stage of chronic kidney disease } \\
\hline & Stage 1 & Stage 2 & Stage 3 & Stage 4 & Stage 5 \\
\hline Over the period of 24 hours & NS & NS & NS & NS & NS \\
\hline During the day & NS & NS & NS & NS & NS \\
\hline At night & $p<0.05$ & $p<0.05$ & NS & $p<0.05$ & NS \\
\hline
\end{tabular}


atherosclerotic lesions is much faster than in patients with hypertension and without diabetes. The progression of atherosclerotic lesions leads to stiffness of vessel walls. Vessels become less sensitive to drugs which are to lower the blood pressure. It is supported by the fact that in both groups of patients the time from the moment of hypertension diagnosis was very similar. This is extremely unfavourable for the prognosis, especially in patients with diabetes.

There were no significant differences in the values of the systolic and diastolic blood pressure and the blood pressure measured around the clock, during the day and at night in patients with diabetes and hypertension at different stages of CKD and in patients without diabetes with hypertension at different stages of CKD. The number of patients whose daily blood pressure is not controlled properly during day and at night increases together with the stage of CKD.

The blood pressure usually increases with the development of renal failure [8]. Interestingly, in both groups of subjects, both in patients with diabetes and hypertension and in patients with hypertension but not suffering from diabetes, the systolic and diastolic blood pressure and the blood pressure measured around the clock, during the day and at night, did not increase significantly together with the progression of CKD. It can also confirm the fact that the patients were aware of their disease and complications and, therefore, remained under medical supervision. Moreover, they took the prescribed anti-hypertensive medicines. However, this is only partially true. As it was shown in the conducted research, the number of patients whose blood pressure was not controlled properly increased significantly, according to the statistics. Interestingly, it concerned both daily pressure, and the pressure during the day and at night. The average increase in blood pressure is a very important factor which strains cardiovascular system. Thus, despite the fact that, in general, there was no increase in average pressure in the individual stages of CKD, the blood pressure in some patients did increase. It suggests that the blood pressure of some patients, certainly strictly obeying the therapeutic recommendations (concerning both non-pharmaceutical - behavioural and pharmaceutical treatement) was better controlled and, therefore, not only reduced the risk of developing cardiovascular complications, but also slowed down the process of renal failure progression. However, the second part of the patients, unfortunately, did not obeyed the therapeutic recommendations or their attitude towards the proposed therapeutic recommendations was too liberal, which increased the risk of developing cardiovascular complications (related to both diabetes and hypertension) and increased the risk of fast renal failure progression.

It should be also noted that the growing number of patients (in both groups) with worse blood pressure control, especially at night, is particularly dangerous. Deterioration in the blood pressure control is a very important factor that deteriorates the quality of life, and reduces the patients' life expectancy.

There are also differences in values of systolic and diastolic blood pressure, during the day and at night between patients with diabetes and hypertension at different stages of CKD. During the measurement of blood pressure during the day in patients with hypertension but without diabetes with stages $2(p=0.048)$ and 3 ( $p=0.018$ ) of CKD the values of diastolic blood pressure were significantly higher than in patients with diabetes and hypertension. During the day, however, the values of pulse pressure in patients with stage 2 $(p=0.006)$ and $3(p=0.035)$ of CKD in patients with diabetes and hypertension were significantly higher than in patients with hypertension but without diabetes. Finally, the values of systolic blood pressure in the patients with diabetes and hypertension with stage 2 of CKD ( $p=0.049$ ) were significantly higher than in patients with hypertension but without diabetes. Also, the values of pulse pressure in patients with diabetes and hypertension with stage $2(p=0.023)$ and stage 3 ( $p=0.003$ ) of CKD were significantly higher than in patients with hypertension but without diabetes. The percentage of patients whose blood pressure was not properly controlled during the day and at night was significantly higher in patients with diabetes and hypertension than in patients without diabetes. And the percentage of patients whose blood pressure was not properly controlled at night was significantly higher in patients with diabetes and hypertension than in patients without diabetes with stage 1 ( $p<0.05), 2$ $(p<0.05)$ and $3(p<0.05)$ of CKD.

Thus, the blood pressure of the patients with diabetes and hypertension and patients with hypertension but without diabetes is, at first glance, controlled similarly at various stages of CKD. However, this is not the whole truth. As it was shown in the above description, the values of diastolic pressure during the day are higher in patients with hypertension but without diabetes at stage 3 and 4 of CKD, and the patients with hypertension and diabetes have significantly higher values of systolic blood pressure at stage 2 of CKD. Higher values of systolic blood pressure are associated with worse prognosis in patients with diabetes and hypertension compared with patients without diabetes. As already noted, this indicates the significant progression of the atherosclerotic lesions in the blood vessels, and 
thus the loss of elasticity of blood vessels. Blood vessels which are damaged by atherosclerotic lesions lead to the increased risk of complications related to heart and brain as well as to peripheral vessels. Interestingly, this applies only to patients with stage 2 and 3 of CKD. This does not apply to patients with stage 4 and 5 of CKD. This suggests that the progression of the disease at more advanced stages of renal failure is not dependent on the cause leading to the disease. It is similar in each patient. What is worse, it is irreversible. One practical observation may be drawn that patients with diabetes and hypertension should undergo the most intensive treatment up to the stage 3 of CKD. During this period, it is still possible to obtain the effects of approximated prognosis observed in patients with hypertension and without diabetes. In stages 4 and 5 irrespective of the cause (diabetes, hypertension) the therapeutic effect is similar. Unfortunately, these stages (stage 4 and 5 of CKD) display a significant deterioration in the quality of life and a substantial decrease in life expectancy.

\section{Limitations of the study}

The obtained research results present numerous cognitive and practical values. The conclusion which may be drawn from the research suggests that the results were influenced by many different factors. Particular attention should be paid to it. The critical remarks concerning the research listed below.

\section{Selection of the study group}

Patients for the study were qualified following the sequence of their admission to the ward and obtaining their consent to be included in the study. The selection method of the study group seemed to be the best of all possible. Unfortunately, some patients, usually in worse clinical condition, did not grant their consent to be considered in the study. In this case the obtained result are the results displayed in patients with a better prognosis and in this case the patients with worse prognosis were not included in the study. This could to some extent affect the results obtained.

\section{Determination of creatinine clearance}

The Cockroft-Gault equation was used to determine the creatinine clearance. It was the most practical one. However, the Cockroft-Gault equation proves to be proper to determine creatinine clearance in patients with good renal function. In patients with poor renal function this formula may slightly fail. In such case it is better to use MDRD formula or a different. This could generate some irregularities when assigning the patients to relevant groups according to the stage of CKD.

\section{Determination of daily blood pressure measurement}

Daily blood pressure measurement was taken in all subjects. The measurement began in the next morning in case of the patients admitted in the morning; the measurement was taken in the morning in case the patients admitted in the evening or at night. This could have had an impact on the achieved study results.

\section{Causes of hypertension}

Causes of hypertensions were not indicated in the subjects. It is conceivable that some patients suffered from secondary hypertension that had not been diagnosed earlier.

\section{Treatment of hypertension}

During daily blood pressure measurement, antihypertensive medicines were taken by the patients who had also taken them before the measurement. Naturally, the medicines had an impact on blood pressure measurements. In addition, the patients took different anti-hypertensive medicines with different pharmacokinetics and different duration of action. This could have a considerable impact on the achieved study results.

\section{Age and sex of subjects}

The subjects' age or sex did not have an impact on the achieved study results. This affects data interpretation to some extent.

\section{Creatinine clearance in subjects}

All subjects were divided into groups depending of creatinine clearance. Unfortunately, the patient group with low creatinine clearance $\left(<15 \mathrm{~mL} / \mathrm{min} / 1.73 \mathrm{~m}^{2}\right)$ featured the lowest number of members. In this case, the result achieved in one person could have an effect on the results of the entire group. The group should have more patients in further studies.

\section{Conclusions}

1. The blood pressure of patients with diabetes and hypertension is controlled to a significantly lesser extent (over the period of 24 hours, during the day and at night) in relation to patients with hypertension without diabetes.

2. The increasing degree of renal failure affects the increase in the number of patients with diabetes and hypertension as well as patients with hypertension without diabetes whose blood pressure is not controlled properly, in particular the patients with diabetes and hypertension.

3. In order to prevent or delay the diabetes and hypertension complication development it is neces- 
sary, to modify the anti-hypertensive treatment in rational but rather aggressive manner, especially in patients with diabetes to achieve the desired therapeutic objective.

\section{REFERENCES}

1. World Health Organization. Global Report on Diabetes, WHO 2016

2. IDF Diabetes Atlas Group. Update of mortality attributable to diabetes for the IDF Diabetes Atlas: estimates for the year 2013. Diabetes Res Clin Pract. 2015; 109(3): 461-465, doi: 10.1016/j. diabres.2015.05.037, indexed in Pubmed: 26119773.

3. Kabakov E, Norymberg C, Osher E, et al. Prevalence of hypertension in type 2 diabetes mellitus: impact of the tightening definition of high blood pressure and association with confounding risk factors. J. Cardiometab. Syndr. 2006; 1(2): 95-101, doi: 10.1111/j.15594564.2006.05513.x, indexed in Pubmed: 17679829.

4. Adler Al. Association of systolic blood pressure with macrovascular and microvascular complications of type 2 diabetes (UKPDS 36): prospective observational study. BMJ. 2000; 321(7258): 412-419. doi: 10.1136/bmj.321.7258.412, indexed in Pubmed: 10938049.

5. UK Prospective Diabetes Study Group. Tight blood pressure control and risk of macrovascular and microvascular complications in type 2 diabetes: UKPDS 38. BMJ. 1998; 317(7160): 703-713, doi: 10.1136/bmj.317.7160.703, indexed in Pubmed: 9732337.

6. Cushman WC, et al. Effects of Intensive Blood-Pressure Control in Type 2 Diabetes Mellitus. N. Engl. J. Med. 2010; 362(17): 1575-1585, doi: 10.1056/nejmoa1001286, indexed in Pubmed: 20228401.

7. UK Prospective Diabetes Study Group. Efficacy of atenolol and captopril in reducing risk of macrovascular and microvascu- lar complications in type 2 diabetes: UKPDS 39. BMJ. 1998; 317(7160): 713-720, doi: 10.1136/bmj.317.7160.713, indexed in Pubmed: 9732338.

8. Chen NC, Hsu CY, Chen CL. The Strategy to Prevent and Regress the Vascular Calcification in Dialysis Patients. Biomed Res Int. 2017; 2017: 9035193, doi: 10.1155/2017/9035193, indexed in Pubmed: 28286773.

9. Taler SJ, Agarwal R, Bakris GL, et al. KDOQI US commentary on the 2012 KDIGO clinical practice guideline for management of blood pressure in CKD. Am J Kidney Dis. 2013; 62(2): 201-213, doi: 10.1053/j.ajkd.2013.03.018, indexed in Pubmed: 23684145.

10. Sarafidis PA, Ruilope LM. Aggressive blood pressure reduction and renin-angiotensin system blockade in chronic kidney disease: time for re-evaluation? Kidney Int. 2014; 85(3): 536-546, doi: 10.1038/ /ki.2013.355, indexed in Pubmed: 24048382.

11. Kabat M. Znaczenie 24-godzinnego pomiaru ciśnienia krwi. Postępy Nauk Medycznych 2002; 2/3: 135-139.

12. KDOQI clinical practice guidelines for chronic kidney disease: evaluation, classification and stratification. Kidney Disease Outcomes Quality Initiative. Am. J. Kidney Dis. 2002; 39(supl.1): 17-222.

13. Emerging Risk Factors Collaboration. Diabetes mellitus, fasting blood glucose concentration, and risk of vascular disease: a collaborative meta-analysis of 102 prospective studies. Lancet. 2010; 375(9733): 2215-2222, doi: 10.1016/s0140-6736(10)60484-9, indexed in Pubmed: 20609967.

14. Widecka K, Grodzicki K, Narkiewicz K, et al. Zasady postępowania w nadciśnieniu tętniczym. Nadciśnienie tętnicze. Nadciśnienie tętnicze. 2011; 15: 55-82.

15. Grupa Robocza Europejskiego Towarzystwa Nadciśnienia Tętniczego (ESH) i Europejskiego Towarzystwa Kardiologicznego (ESC) do spraw postępowania w nadciśnieniu tętniczym. Wytyczne ESH/ /ESC dotyczące postępowania w nadciśnieniu tętniczym w 2013 roku. Nadciśnienie Tętnicze. 2013; 71: 69-168. 